\title{
Heavy Metalspatial Distribution and Pollution Assessment in the Surface Sediments of the North - Western Black Sea Shelf
}

\author{
ANDRA BUCSE ${ }^{1,2}$, DAN VASILIU ${ }^{1 *}$, SORIN BALAN ${ }^{1}$, OANA CRISTINA PARVULESCU ${ }^{2 *}$, \\ TANASE DOBRE ${ }^{2}$ \\ ${ }^{1}$ National Institute for Research and Development on Marine Geology and Geoecology - GeoEcoMar, 23-25 Dimitrie \\ Onciul Str., 024053, Bucharest, Romania \\ ${ }^{2}$ University Politehnica Bucharest, Chemical and Biochemical Engineering Department, 1-3 Gheorghe Polizu Str., 011061, \\ Bucharest, Romania
}

\begin{abstract}
August 2018 from the Romanian inner shelf (Nord-Western Black Sea). Concentrations of some metals ( $\mathrm{Al}, \mathrm{Cr}, \mathrm{Cu}, \mathrm{Ni}, \mathrm{Zn}, \mathrm{As}, \mathrm{Pb}$, and $\mathrm{Hg}$ ), TOC content, and grain size of sediment samples were determined by specific techniques. The order of accumulation of heavy metals was $\mathrm{Zn}>\mathrm{Cr}>\mathrm{Ni}>\mathrm{Cu}>\mathrm{Pb}>\mathrm{As}>\mathrm{Hg}$. Multivariate analysis indicated that $\mathrm{As}, \mathrm{Ni}, \mathrm{Cu}, \mathrm{Zn}, \mathrm{Pb}$, and $\mathrm{Hg}$ concentrations had similar behavior and they were positively correlated with the clay content, whereas $\mathrm{Al}$ and $\mathrm{Cr}$ concentrations presented close patterns and they were negatively correlated with the water depth. Sediment pollution assessment indices (enrichment factor, contamination factor, and geo-accumulation index) suggested no/low pollution for most of the metals analyzed, excepting for $\mathrm{Pb}$ and $\mathrm{Hg}$ (moderate pollution). Values of pollution indices highlighted a higher sediment pollution with $\mathrm{Pb}$ and $\mathrm{Hg}$ along the Danube's plume direction, in the oil platform area (eastern edge of the Portita Bay), and partially in the Constanta and Mangalia area, suggesting the influence of port activities, tourism, urban wastewater discharges, oil and gas extraction.
\end{abstract}

Keywords: Black Sea, heavy metals, sediments, pollution indices, multivariate analysis

\section{Introduction}

Heavy metals are natural components of the Earth's crust, but in the last few decades they are released in the marine environment through sea port activities (e.g., harbors, antifouling paints), oil and gas extraction, urbanization, industry, etc. On the other hand, the riverine discharges carry on high amounts of pollutants into the sea, either dissolved or adsorbed on the fine suspended particles [1].

North-Western (NW) Black Sea has faced to significant anthropogenic pressures since the 1970s, most of them linked to the Danube's discharges, which heavily impacted the Romanian shelf. The strong development of the industry, agriculture, and urbanization in the Danube's catchment area, along with the sea-based activities, during the last decades of the $20^{\text {th }}$ century, led to a considerable increase in the heavy metals pollution level [2]. After 2000, once the Romania has started to implement the Water Framework Directive (2000/60/EC) and later Marine Strategy Framework Directive (2008/56/EC), the heavy metal introduction in the marine ecosystem has showed a decreasing trend. However, the heavy metal pollution still remains a major concern considering their accumulative behavior, which depends on various factors, including sediment type, total organic carbon (TOC) content, water depth [3-7].

Determination of metal concentrations in the surface sediments is essential to assess pollution level and establish the main factors influencing metal contamination. Some heavy metals, e.g., $\mathrm{Cu}, \mathrm{Zn}, \mathrm{Fe}$, $\mathrm{Cr}$, are essential elements for life, whereas others $(\mathrm{Pb}, \mathrm{Hg}, \mathrm{Ni}, \mathrm{As}, \mathrm{Cd})$ can be extremely harmful even at very low concentrations [7-13]. Especially for these toxic metals, it is important to identify their source (natural or anthropogenic), to assess the contamination level, and identify factors affecting their accumulation.

\footnotetext{
$\overline{\text { *email: oanaparvulescu@yahoo.com; dan.vasiliu@geoecomar.ro }}$
} 
Pollution indices, such as enrichment factor $(E F)$, contamination factor $(C F)$, and geoaccumulation index $\left(I_{g e o}\right)$, are widely used to evaluate the effect of anthropogenic activities on sediment quality $[3,4,6,7,14-19]$. Furthermore, multivariate exploratory techniques, especially Principal Component Analysis (PCA) and Hierarchical Cluster Analysis (HCA), can be successfully applied to determine the metal source and establish the impact of environmental factors on contamination level $[3-7,14,18,20]$.

This study has aimed at: (i) describing the spatial distribution of some trace elements (As, $\mathrm{Cr}, \mathrm{Ni}$, $\mathrm{Cu}, \mathrm{Zn}, \mathrm{Pb}$, and $\mathrm{Hg}$ ) in the NW Black Sea sediments; (ii) assessing the sediment quality using some pollution indices $\left(E F, C F\right.$, and $\left.I_{g e o}\right)$; (iii) estimating the main environmental factors influencing the metal distribution and determining clusters of stations having dissimilar metal accumulation in the surface sediments by applying PCA and HCA.

\section{Materials and methods}

\section{Study area}

Sediment samples were collected from 22 sampling stations (water depths within 12-67 m), covering the Romanian inner shelf waters (NW Black Sea), during the research cruise aboard $R / V$ Mare Nigrum conducted in August 2018. The stations considered in this study were near Sulina (SU01 and SU02), Sfantu Gheorghe (SG01, SG03-05), Portita (PO01, PO02, PO04, and PO05), Constanta (CT01-05), Eforie (EF02), Tuzla (TZ18), and Mangalia (MA04-08). Spatial distribution of selected stations is considered representative for the assessment of the metal pollution along the Romanian coast of the Black Sea. The map of the sampling stations considered in this study is shown in Figure 1, while their main characteristics in terms of coordinates and water depths are summarized in Table 1.

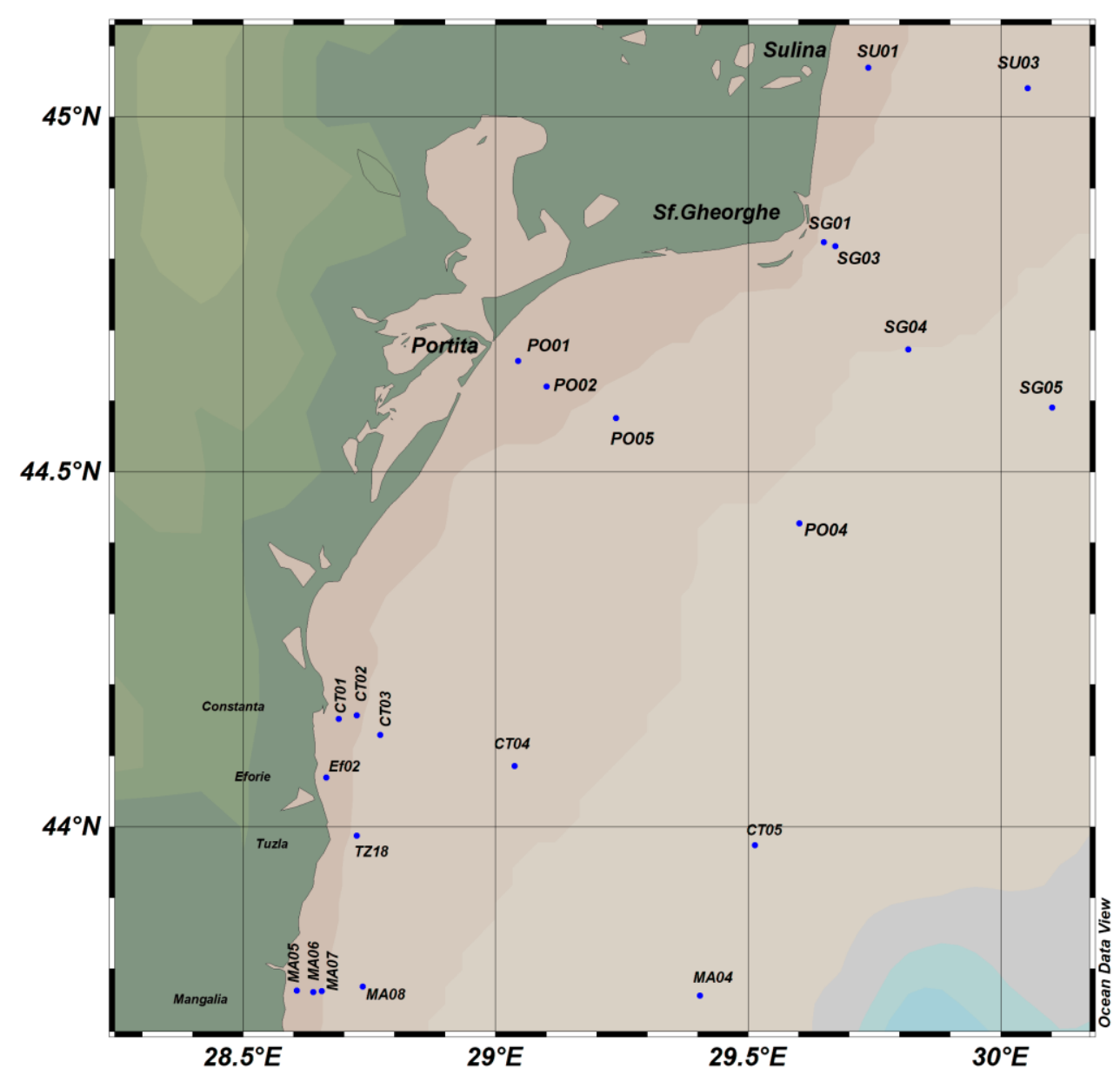

Figure 1. Map of sampling stations 
Table 1. Main characteristics of sampling stations

\begin{tabular}{|l|l|l|l|l|}
\hline No. & Station & $\begin{array}{c}\text { Latitude } \\
\left({ }^{\circ}\right)\end{array}$ & $\begin{array}{c}\text { Longitude } \\
\left({ }^{\circ}\right)\end{array}$ & $\begin{array}{c}\text { Water depth } \\
h(\mathrm{~m})\end{array}$ \\
\hline 1 & SU01 & 45.0700 & 29.7371 & 15 \\
\hline 2 & SU03 & 45.0412 & 30.0526 & 35 \\
\hline 3 & SG01 & 44.8240 & 29.6498 & 20 \\
\hline 4 & SG03 & 44.8186 & 29.6719 & 32.5 \\
\hline 5 & SG04 & 44.6730 & 29.8162 & 52 \\
\hline 6 & SG05 & 44.5911 & 30.1018 & 65 \\
\hline 7 & PO01 & 44.6566 & 29.0436 & 13.5 \\
\hline 8 & PO02 & 44.6203 & 29.1008 & 20 \\
\hline 9 & PO04 & 44.4281 & 29.6008 & 42.6 \\
\hline 10 & PO05 & 44.5761 & 29.2383 & 30.2 \\
\hline 11 & CT01 & 44.1525 & 28.6886 & 19 \\
\hline 12 & CT02 & 44.1569 & 28.7244 & 28 \\
\hline 13 & CT03 & 44.1300 & 28.7710 & 34.5 \\
\hline 14 & CT04 & 44.0860 & 29.0372 & 45.9 \\
\hline 15 & CT05 & 43.9743 & 29.5129 & 64.8 \\
\hline 16 & EF02 & 44.0697 & 28.6645 & 16 \\
\hline 17 & TZ18 & 43.9880 & 28.7245 & 33.8 \\
\hline 18 & MA04 & 43.7622 & 29.4036 & 67 \\
\hline 19 & MA05 & 43.7696 & 28.6061 & 16.8 \\
\hline 20 & MA06 & 43.7673 & 28.6390 & 27 \\
\hline 21 & MA07 & 43.7689 & 28.6550 & 35 \\
\hline 22 & MA08 & 43.7748 & 28.7360 & 44.8 \\
\hline
\end{tabular}

\section{Sediments sampling and analysis}

Sediment samples were collected from the surface layer (0-2 cm depth) using a grab sampler with an opening mouth of $0.14 \mathrm{~m}^{2}$. Each sample was subsampled for grain size and geochemical analyses, respectively. Sediment subsamples were stored in plastic bags and kept at $0-4{ }^{\circ} \mathrm{C}$ until subsequent analyses.

Grain sizes of sediments were determined with a Mastersizer 2000 laser diffraction granulometer (Mastersizer 2000E, ver. 5.20) and associated dispersion units (Malvern Instruments, U.K), measurement precision being of $1 \%$ and result reproducibility below $1 \%$. Separate granulometric fractions are in accordance with Udden-Wentworth dimensional scale with sand/silt and silt/clay boundaries of $63 \mu \mathrm{m}$ and $4 \mu \mathrm{m}$, respectively. The Shepard's ternary diagram was used for lithological classification of sediment samples [21].

Before geochemical analyses, the sediments were oven dried $\left(24-48 \mathrm{~h} / 105^{\circ} \mathrm{C}\right)$, ground, and homogenized with a mortar and pestle. TOC concentrations were determined using titration method [22].

Concentrations of $\mathrm{Al}, \mathrm{Cr}, \mathrm{Cu}, \mathrm{Ni}, \mathrm{Zn}, \mathrm{As}$, and $\mathrm{Pb}$ were measured by $\mathrm{X}$-ray fluorescence spectrometry using an EDXRF Spectro Xepos spectrometer (Germany). Total $\mathrm{Hg}$ content was determined using an automatic mercury analyzer DMA 80 Milestone (Italy) by solid sample thermal decomposition, identification, and quantification of total $\mathrm{Hg}$ by atomic absorption spectrophotometry. To validate the analytical methodology, a certified reference material NCS DC 73022 was used. Measured and certified values of element/compound concentrations were compared (Table 2). For this material, all measured values were statistically similar to the certified values $(p<0.05)$, demonstrating the reliability of the methodology and the estimated concentrations. 
Table 2. Measured and certified values of standard material ncs dc 73022

\section{Pollution indices}

\begin{tabular}{|l|l|l|}
\hline Element/compound & $\begin{array}{c}\text { Measured value } \\
(\mathrm{mg} / \mathrm{kg})\end{array}$ & $\begin{array}{c}\text { Certified value } \\
(\mathrm{mg} / \mathrm{kg})\end{array}$ \\
\hline $\mathrm{Cr}$ & 69.8 & $72 \pm 3$ \\
\hline $\mathrm{Al}_{2} \mathrm{O}_{3}$ & 13.22 & $13.61 \pm 0.12$ \\
\hline $\mathrm{As}$ & 291 & $304 \pm 20$ \\
\hline $\mathrm{Ni}$ & 30.4 & $29 \pm 1$ \\
\hline $\mathrm{Cu}$ & 497 & $483 \pm 20$ \\
\hline $\mathrm{Pb}$ & 131 & $126 \pm 5$ \\
\hline $\mathrm{Zn}$ & 874 & $874 \pm 19$ \\
\hline $\mathrm{Hg}$ & 0.113 & $0.115 \pm 0.023$ \\
\hline
\end{tabular}

The intensity of coastal sediment pollution was assessed based on several indices, i.e., enrichment factor $(E F)$, contamination factor $(C F)$, and geo-accumulation index $\left(I_{g e o}\right)$. Since no background data of metals in uncontaminated marine sediments in the study area are available, the values of global Earth's shale concentration of metal $i, c_{i, b}(\mathrm{mg} / \mathrm{kg}$ dry matter), reported by Turekian and Wedepohl (1961) [23], were used as background values, i.e., $c_{A l, b}=80000 \mathrm{mg} / \mathrm{kg}, c_{A s, b}=13 \mathrm{mg} / \mathrm{kg}, c_{P b, b}=20 \mathrm{mg} / \mathrm{kg}$, $c_{C u, b}=45 \mathrm{mg} / \mathrm{kg}, c_{H g, b}=0.08 \mathrm{mg} / \mathrm{kg}, c_{N i, b}=68 \mathrm{mg} / \mathrm{kg}, c_{C r, b}=90 \mathrm{mg} / \mathrm{kg}$, and $c_{Z n, b}=95 \mathrm{mg} / \mathrm{kg}$.

Pollution indices were determined based on Eqs. (1)-(3), where $c_{i, s}$ is the concentration of metal $i$ in the sample and $c_{i, b}$ the background concentration of metal $i$. Pollution levels estimated depending on the values of pollution indices are specified in Table 3 .

$$
\begin{gathered}
E F=E F_{i}=\frac{c_{i, s}}{c_{i, b}} \frac{c_{A l, b}}{c_{A l, s}} \\
C F=C F_{i}=\frac{c_{i, s}}{c_{i, b}} \\
I_{g e o}=I_{g e 0, i}=\log _{2}\left(\frac{c_{i, s}}{1.5 c_{i, b}}\right)
\end{gathered}
$$

\begin{tabular}{|c|c|c|c|c|}
\hline No. & Index & Values & Pollution level & Reference \\
\hline \multirow{7}{*}{1} & \multirow{7}{*}{ Enrichment factor $(E F)$} & $<1$ & No enrichment & \multirow{7}{*}[4-7,14,18,19]{} \\
\hline & & $1-3$ & Minor enrichment & \\
\hline & & $3-5$ & Moderate enrichment & \\
\hline & & $5-10$ & Moderately severe enrichment & \\
\hline & & $10-25$ & Severe enrichment & \\
\hline & & $25-50$ & Very severe enrichment & \\
\hline & & $>50$ & Extremely severe enrichment & \\
\hline \multirow{4}{*}{2} & \multirow{4}{*}{ Contamination factor $(C F)$} & $<1$ & No/low contamination & \multirow{4}{*}[7,14,15,19]{} \\
\hline & & $1-3$ & Moderate contamination & \\
\hline & & $3-6$ & Considerable contamination & \\
\hline & & $>6$ & Very high contamination & \\
\hline \multirow{7}{*}{3} & \multirow{7}{*}{ Geo-accumulation index $\left(I_{g e o}\right)$} & $<0$ & Uncontamined & \multirow{7}{*}[3,4,7,14,16,17,19]{} \\
\hline & & $0-1$ & Uncontaminated to moderately & \\
\hline & & $1-2$ & Moderately contaminated & \\
\hline & & $2-3$ & Moderately to heavily contaminated & \\
\hline & & $3-4$ & Heavily contaminated & \\
\hline & & $4-5$ & Heavily to extremely contaminated & \\
\hline & & $>5$ & Extremely contaminated & \\
\hline
\end{tabular}

Table 3. Pollution levels depending on the values of pollution indices

\section{Data processing}


Spatial distributions of TOC content, metal concentrations, and pollution indices were visualized using the Ocean Data View (ODV) software, ver. 4.7.10 [24]. Univariate analysis (ANOVA one way) and multivariate exploratory techniques (PCA and HCA) were performed using Statistica, ver. 10 (StatSoft, Inc).

\section{Results and discussions Experimental data}

Composition (expressed as percentages $(P)$ of sand, silt, and clay) and type of surface $(0-2 \mathrm{~cm})$ sediments in the area considered in the study are specified in Table 4. Depending on their composition, the sediment types vary from silty sand to clayey silt.

Generally, the studied area is covered by clayey silt, except 6 stations. Silty sand sediments were found at the shallowest stations (water depths less than $20 \mathrm{~m}$ ) located south of Danube's mouth areas, where the highest percentages of sand were determined, i.e., $53.67 \%$ at PO01, $61.42 \%$ at CT01, and $66.02 \%$ at EF02. Sandy silt sediments were collected from the stations in the Mangalia area, either from the shallowest stations, MA05 $\left(P_{\text {sand }}=32.77 \%\right)$ and MA06 $\left(P_{\text {sand }}=36.75 \%\right)$, or from the deepest station, MA04 $\left(P_{\text {sand }}=26.46 \%\right)$. The highest percentages of clay $(36.90-48.50 \%)$ were observed in the Portita Bay (excepting the shallowest station, PO01) and in front of Sf. Gheorghe mouth (SG01), while the silt was dominant in front of Sulina mouth $(65.40 \%$ at SU01 and $63.52 \%$ at SU03), at TZ18 (70.94\%) and MA07 (71.67\%) as well as along Sf. Gheorghe-SE and Constanta-SE transects, except the shallowest stations, SG01 and CT01 (66.91-67.99\% and 63.58-69.04\%, respectively).

Table 4. Composition and type of surface sediments

\begin{tabular}{|c|c|c|c|c|c|}
\hline No. & Station & $\begin{array}{c}\text { Sand content } \\
P_{\text {sand }}(\%)\end{array}$ & $\begin{array}{c}\text { Silt content } \\
P_{\text {silt }}(\%)\end{array}$ & $\begin{array}{c}\text { Clay content } \\
P_{\text {clay }}(\%)\end{array}$ & Sediment type \\
\hline 1 & SU01 & 2.18 & 65.40 & 32.42 & clayey silt \\
\hline 2 & SU03 & 13.47 & 63.52 & 23.01 & clayey silt \\
\hline 3 & SG01 & 1.01 & 50.50 & 48.50 & clayey silt \\
\hline 4 & SG03 & 5.40 & 66.91 & 27.69 & clayey silt \\
\hline 5 & SG04 & 5.29 & 67.66 & 27.04 & clayey silt \\
\hline 6 & SG05 & 6.09 & 67.99 & 25.92 & clayey silt \\
\hline 7 & PO01 & 53.67 & 40.27 & 6.07 & silty sand \\
\hline 8 & PO02 & 0.40 & 54.81 & 44.79 & clayey silt \\
\hline 9 & PO04 & 1.52 & 61.58 & 36.90 & clayey silt \\
\hline 10 & PO05 & 1.70 & 50.96 & 47.34 & clayey silt \\
\hline 11 & CT01 & 61.42 & 29.54 & 9.04 & silty sand \\
\hline 12 & CT02 & 4.65 & 64.98 & 30.38 & clayey silt \\
\hline 13 & CT03 & 3.28 & 69.04 & 27.68 & clayey silt \\
\hline 14 & CT04 & 5.04 & 63.58 & 31.38 & clayey silt \\
\hline 15 & CT05 & 5.23 & 64.75 & 30.02 & clayey silt \\
\hline 16 & EF02 & 66.02 & 29.49 & 4.50 & silty sand \\
\hline 17 & TZ18 & 5.82 & 70.94 & 23.24 & clayey silt \\
\hline 18 & MA04 & 26.46 & 47.57 & 25.98 & sandy silt \\
\hline 19 & MA05 & 32.77 & 54.48 & 12.75 & sandy silt \\
\hline 20 & MA06 & 36.75 & 51.82 & 11.43 & sandy silt \\
\hline 21 & MA07 & 4.37 & 71.67 & 23.97 & clayey silt \\
\hline 22 & MA08 & 17.87 & 54.96 & 27.17 & clayey silt \\
\hline
\end{tabular}

The values of TOC and metal concentrations in the surface sediments for each station are specified in Table 5. Descriptive statistics in terms of minimum (min) and maximum (max) values, mean, median, standard deviation (SD), and coefficient of variation (CV) for TOC and each metal concentration are also summarized in Table 5.

Data presented in Table 5 and Fig. 2 highlight TOC concentrations in the surface sediments of the investigated area between $0.092 \%$ and $1.779 \%$, with a minimum in front of the Constanta harbor (CT01) and a maximum in the deepest station from the Portita Bay (PO04). Lower TOC concentrations $(<0.5 \%)$ were observed at stations PO01 and MA05, while quite high concentrations 
(>1.5\%) were found at stations SG04, SG05, PO04, and CT05, where the Danube's plume influence is stronger, as well as at stations MA06 and MA07.

Table 5. Total organic carbon and metal concentrations in the surface sediments

\begin{tabular}{|c|c|c|c|c|c|c|c|c|c|c|}
\hline No. & Station & $\begin{array}{l}\text { TOC } \\
(\%)\end{array}$ & $\begin{array}{c}c_{A l, s} \\
(\mathrm{mg} / \mathrm{kg})\end{array}$ & $\begin{array}{c}c_{A s, s} \\
(\mathrm{mg} / \mathrm{kg})\end{array}$ & $\begin{array}{c}c C r, s \\
(\mathrm{mg} / \mathrm{kg})\end{array}$ & $\begin{array}{c}c_{N i, s} \\
(\mathrm{mg} / \mathrm{kg})\end{array}$ & $\begin{array}{c}c C u, s \\
(\mathrm{mg} / \mathrm{kg}) \\
\end{array}$ & $\begin{array}{c}c Z n, s \\
(\mathrm{mg} / \mathrm{kg})\end{array}$ & $\begin{array}{c}c P b, s \\
(\mathrm{mg} / \mathrm{kg})\end{array}$ & $\begin{array}{c}\begin{array}{c}\text { CHg,s } \\
(\mathrm{mg} / \mathrm{kg})\end{array} \\
\end{array}$ \\
\hline 1 & SU01 & 0.993 & 63140 & 14.43 & 91.75 & 56.20 & 52.08 & 110.5 & 33.18 & 0.170 \\
\hline 2 & SU03 & 0.905 & 23590 & 5.665 & 43.28 & 26.09 & 20.13 & 56.35 & 17.24 & 0.060 \\
\hline 3 & SG01 & 1.098 & 64930 & 15.71 & 100.55 & 58.35 & 46.67 & 115.0 & 35.04 & 0.215 \\
\hline 4 & SG03 & 1.237 & 60640 & 17.16 & 94.90 & 59.30 & 51.80 & 115.5 & 36.30 & 0.140 \\
\hline 5 & SG04 & 1.732 & 31900 & 11.40 & 58.74 & 38.24 & 32.13 & 74.70 & 29.17 & 0.115 \\
\hline 6 & SG05 & 1.717 & 34170 & 7.680 & 49.05 & 42.36 & 35.19 & 71.65 & 25.90 & 0.150 \\
\hline 7 & PO01 & 0.308 & 50550 & 4.965 & 75.30 & 31.87 & 13.72 & 51.55 & 14.46 & 0.040 \\
\hline 8 & PO02 & 0.941 & 56040 & 10.06 & 92.60 & 52.00 & 38.23 & 100.5 & 31.78 & 0.195 \\
\hline 9 & PO04 & 1.779 & 57010 & 11.70 & 93.55 & 58.65 & 52.47 & 118.5 & 42.07 & 0.230 \\
\hline 10 & PO05 & 1.152 & 56980 & 10.31 & 90.80 & 52.70 & 41.17 & 103.0 & 33.13 & 0.195 \\
\hline 11 & CT01 & 0.092 & 47750 & 4.530 & 72.75 & 24.83 & 9.290 & 41.51 & 13.56 & 0.030 \\
\hline 12 & CT02 & 0.618 & 53890 & 10.03 & 88.65 & 41.00 & 22.98 & 72.20 & 22.69 & 0.085 \\
\hline 13 & CT03 & 1.147 & 59540 & 11.36 & 96.95 & 52.95 & 38.69 & 108.5 & 33.10 & 0.155 \\
\hline 14 & CT04 & 1.291 & 35960 & 9.160 & 56.95 & 36.35 & 28.81 & 77.05 & 26.71 & 0.120 \\
\hline 15 & CT05 & 1.650 & 22510 & 5.570 & 27.74 & 36.74 & 33.42 & 55.80 & 24.54 & 0.090 \\
\hline 16 & EF02 & 1.202 & 46550 & 4.205 & 66.15 & 24.52 & 6.950 & 40.57 & 13.15 & 0.020 \\
\hline 17 & TZ18 & 0.909 & 54120 & 6.455 & 88.95 & 36.39 & 19.03 & 63.75 & 20.76 & 0.070 \\
\hline 18 & MA04 & 0.999 & 19910 & 3.420 & 26.26 & 19.28 & 13.11 & 27.96 & 11.58 & 0.040 \\
\hline 19 & MA05 & 0.142 & 42020 & 3.790 & 76.30 & 22.65 & 7.450 & 42.32 & 12.71 & 0.070 \\
\hline 20 & MA06 & 1.597 & 40540 & 4.230 & 84.95 & 23.84 & 6.865 & 36.84 & 13.15 & 0.030 \\
\hline 21 & MA07 & 1.589 & 54850 & 15.31 & 78.50 & 47.77 & 32.24 & 94.15 & 27.87 & 0.140 \\
\hline 22 & MA08 & 0.609 & 29790 & 7.590 & 57.80 & 30.50 & 20.16 & 52.60 & 17.69 & 0.120 \\
\hline \multicolumn{2}{|r|}{ Min } & 0.092 & 19910 & 3.420 & 26.26 & 19.28 & 6.865 & 27.96 & 11.58 & 0.020 \\
\hline \multicolumn{2}{|c|}{ Max } & 1.779 & 64930 & 17.16 & 100.6 & 59.30 & 52.47 & 118.5 & 42.07 & 0.230 \\
\hline \multicolumn{2}{|c|}{ Mean } & 1.078 & 45745 & 8.850 & 73.29 & 39.66 & 28.30 & 74.11 & 24.35 & 0.113 \\
\hline \multicolumn{2}{|c|}{ Median } & 1.123 & 49150 & 8.420 & 77.40 & 37.49 & 30.47 & 71.93 & 25.22 & 0.118 \\
\hline \multicolumn{2}{|c|}{ SD } & 0.500 & 13980 & 4.232 & 22.26 & 13.29 & 15.30 & 29.49 & 9.195 & 0.064 \\
\hline \multicolumn{2}{|c|}{$\mathrm{CV}$} & 0.464 & 0.306 & 0.478 & 0.304 & 0.335 & 0.541 & 0.398 & 0.378 & 0.569 \\
\hline
\end{tabular}

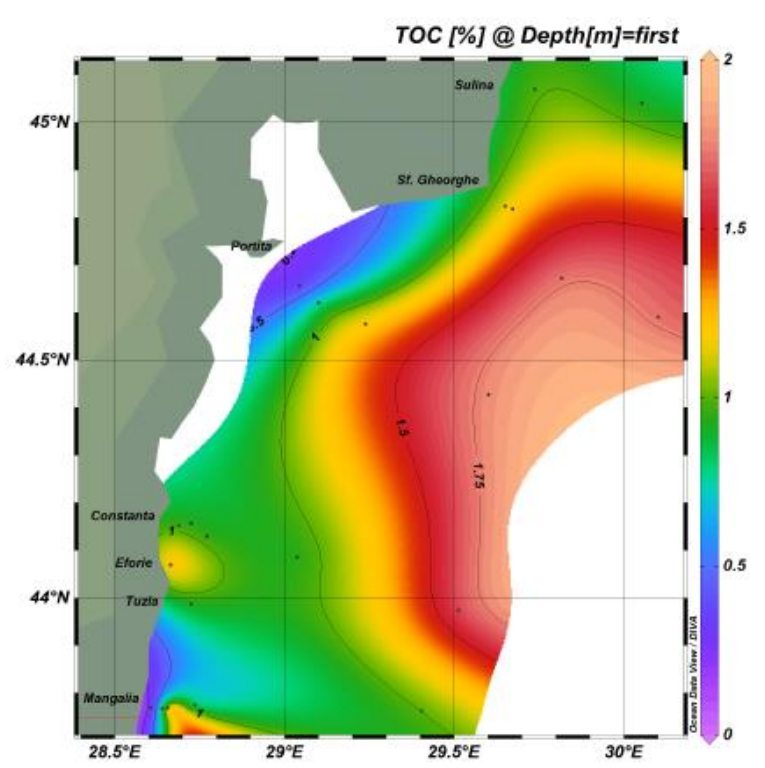

Figure 2. TOC spatial distribution in the surface sediments of the Romanian inner shelf

Data summarized in Table 3 emphasize that metal concentrations in the surface sediments present a relatively large spatial variability in the studied area, percent CVs ranging from $30.4 \%$ (for $\mathrm{Cr}$ ) to 
$56.9 \%$ (for $\mathrm{Hg}$ ). Spatial distributions of metals in the surface sediments, which are shown in Fig. 3, highlight the following issues:

(i) the highest values of Al concentration, i.e., 60640-64930 mg/kg, were detected in the Danube's mouth area (SU01, SG01, and SG03), due to the strong influence of the Danube's input, whereas minimum values (19910 and $22510 \mathrm{mg} / \mathrm{kg}$ ) were found in the deepest stations from the southern part of the studied area (MA04 and CT05);

(ii) the highest values of $\mathrm{Cr}$ concentration $(>90 \mathrm{mg} / \mathrm{kg})$ were noticed not only in the Danube's mouth area (SU01, SG01, and SG03), but also in the Portita Bay (PO02, PO04, and PO05) and Constanta area (CT03); similar to Al, the lowest values of Cr concentration (26.26 and 27.74 mg/kg) were measured at the deepest stations from the southern part of the studied area (MA04 and CT05);

(iii) $\mathrm{Ni}, \mathrm{Cu}$, and $\mathrm{Zn}$ had similar concentration patterns, with higher values $(58.35-59.30 \mathrm{mg} / \mathrm{kg}$, $46.67-52.47 \mathrm{mg} / \mathrm{kg}$, and $110.5-118.5 \mathrm{mg} / \mathrm{kg}$ ) in the Danube's mouth area (SU01, SG01, and SG03) and at the deepest station of the Portita Bay (PO04); minimum values of $\mathrm{Ni}$ and $\mathrm{Zn}$ concentration $(19.28 \mathrm{mg} / \mathrm{kg}$ and $27.96 \mathrm{mg} / \mathrm{kg}$ ) were measured at station MA04, while the lowest levels of $\mathrm{Cu}$ concentration $(6.865-7.450 \mathrm{mg} / \mathrm{kg}$ ) were detected at shallower stations EF02, MA05, and MA06;

(iv) the highest levels of As concentration $(15.71 \mathrm{mg} / \mathrm{kg}$ and $17.16 \mathrm{mg} / \mathrm{kg}$ ) were at stations SG01 and SG03, while maximum values of $\mathrm{Pb}$ and $\mathrm{Hg}$ concentration $(42.07 \mathrm{mg} / \mathrm{kg}$ and $0.23 \mathrm{mg} / \mathrm{kg}$ ) were at station PO04; minimum values of As and $\mathrm{Pb}$ concentration $(3.42 \mathrm{mg} / \mathrm{kg}$ and $11.58 \mathrm{mg} / \mathrm{kg})$ were at station MA04, while the lowest level of $\mathrm{Hg}$ concentration $(0.02 \mathrm{mg} / \mathrm{kg})$ was at station EF02.
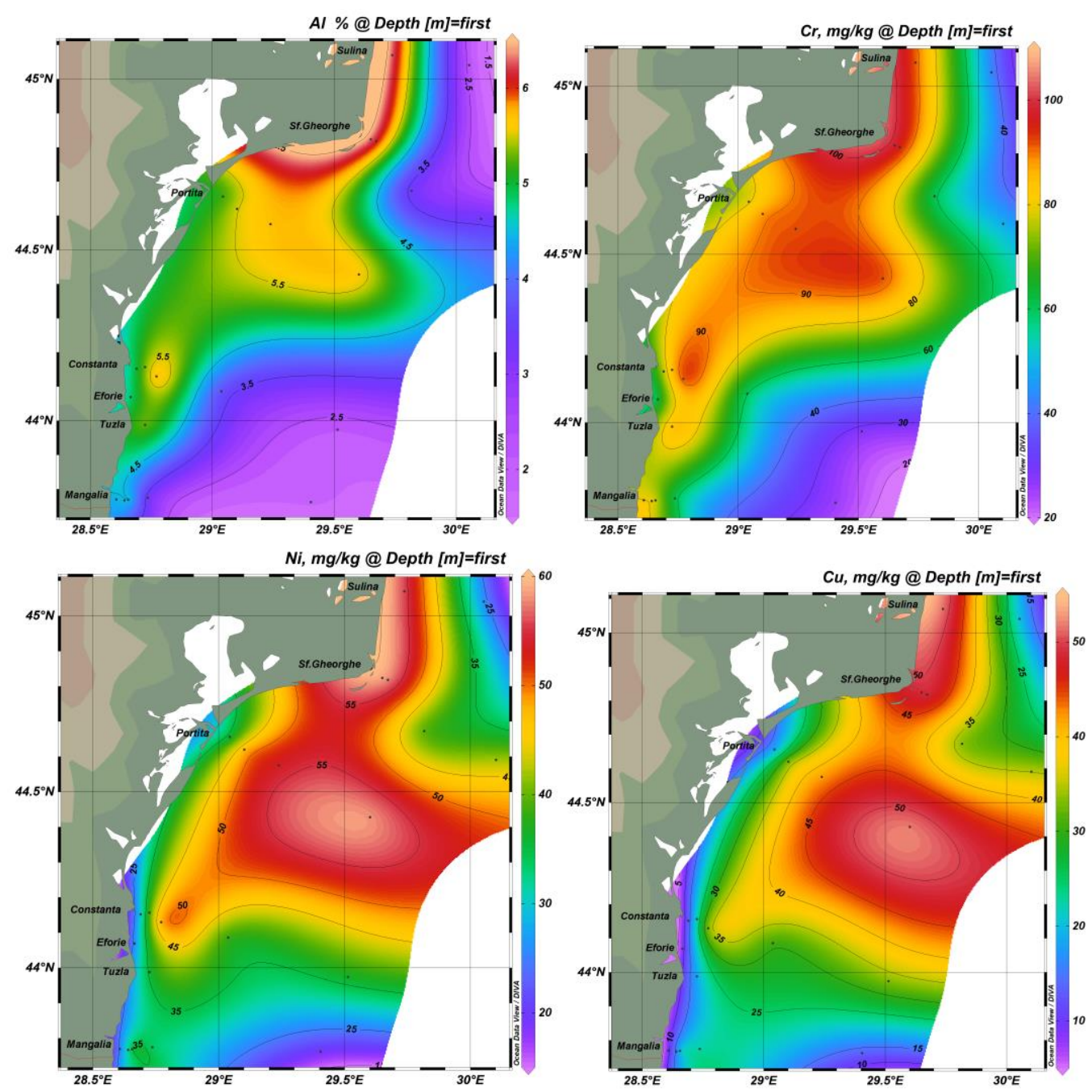

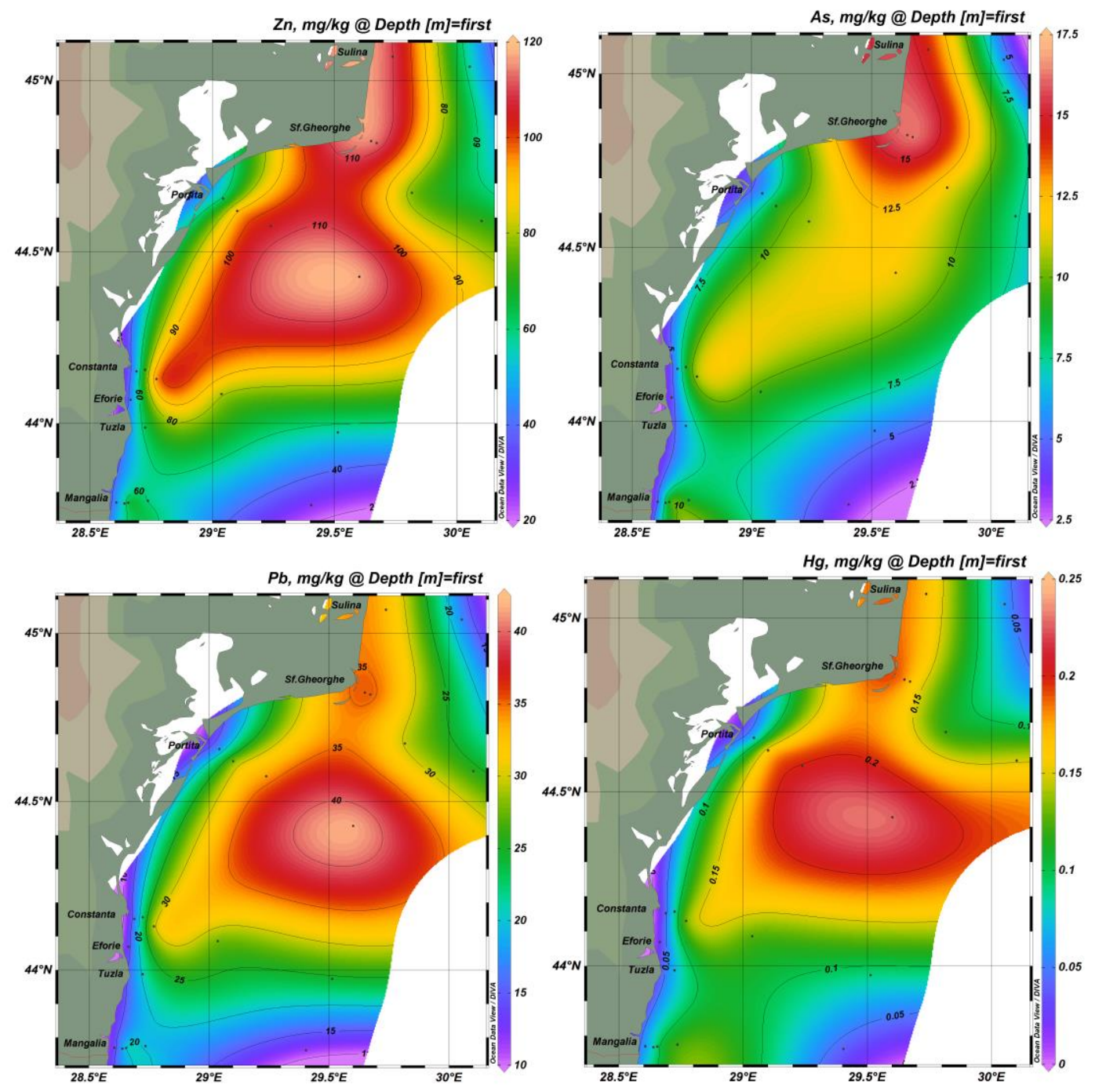

Figure 3. Spatial distribution of $\mathrm{Al}, \mathrm{Cr}, \mathrm{Ni}, \mathrm{Cu}, \mathrm{Zn}, \mathrm{As}, \mathrm{Pb}$, and $\mathrm{Hg}$ in the surface sediments of the Romanian inner shelf

Previous works carried out in the period 1997-2007 showed also a large spatial variability of the heavy metals in the surface sediments of the Romanian shelf [25]. Generally, the metal concentrations determined within 1997-2007 were quite higher than the values measured in this study, e.g., $c_{C r, s}=34.17-144.26 \mathrm{mg} / \mathrm{kg}, \quad c_{N i, s}=63.69-87.84 \mathrm{mg} / \mathrm{kg}, \quad c_{C u, s}=3.40-185.49 \mathrm{mg} / \mathrm{kg}, \quad c_{P b, s}=5.25-119.75$ $\mathrm{mg} / \mathrm{kg}, c_{H g, s}=0.022-0.61 \mathrm{mg} / \mathrm{kg}$.

\section{Statistical processing of experimental data}

PCA, which was performed on 8 metal (Al, $\mathrm{Cr}, \mathrm{Ni}, \mathrm{Cu}, \mathrm{Zn}, \mathrm{As}, \mathrm{Pb}$, and $\mathrm{Hg}$ ) concentrations, TOC content, water depth, percentages of sand, silt, and clay, highlighted two principal components (PCs) with eigenvalues greater than 1 , which account for $84.51 \%$ of total variance (TV). The results shown in Figure 4 and Table 6 emphasize the following aspects: (i) PC1, explaining $61.96 \%$ of TV, is characterized by high negative loads for $\mathrm{As}, \mathrm{Ni}, \mathrm{Cu}, \mathrm{Zn}, \mathrm{Pb}, \mathrm{Hg}$, and clay contents as well as a high positive load for sand percentage; (ii) PC2, accounting for $22.56 \%$ of TV, presents a high positive load for water depth $(h)$ as well as high negative loads for $\mathrm{Al}$ and $\mathrm{Cr}$ concentrations. Pearson correlation coefficient matrix (Table 7) confirms: (i) high positive correlations among $\mathrm{As}, \mathrm{Ni}, \mathrm{Cu}, \mathrm{Zn}, \mathrm{Pb}, \mathrm{Hg}$, and clay contents, high negative correlation between clay and sand percentages $\left(P_{\text {clay }}\right.$ and $\left.P_{\text {sand }}\right)$, as well as high negative correlations between $P_{\text {sand }}$ and concentration of each metal in this group; (ii) high 
positive correlation between $\mathrm{Al}$ and $\mathrm{Cr}$ contents $\left(c_{A l, s}\right.$ and $\left.c_{C r, s}\right)$ as well as high negative correlations between $h$ and $c_{A l, s}$ and $h$ and $c_{C r, s}$.

Accordingly, $\mathrm{As}, \mathrm{Ni}, \mathrm{Cu}, \mathrm{Zn}, \mathrm{Pb}$, and $\mathrm{Hg}$ concentrations have similar behavior and they are positively correlated with clay content, whereas $\mathrm{Al}$ and $\mathrm{Cr}$ contents present close patterns and they are negatively correlated with water depth. More studies in the related literature pointed out that clay particles are important carriers of heavy metals as well as that the water depth can have a significant effect on spatial distributions of metals in the surface sediments [4-7].

Data depicted in Figs. 5 and 6 reveal three main clusters, i.e.: (i) cluster I, consisting of stations PO01, CT01, EF02, MA05, and MA06, characterized by the lowest values of $h(13.5-27 \mathrm{~m}), P_{\text {clay }}$ $(4.50-12.75 \%), c_{A s, s}(3.79-4.97 \mathrm{mg} / \mathrm{kg}), c_{C u, s}(6.87-13.72 \mathrm{mg} / \mathrm{kg}), c_{P b, s}(12.71-14.46 \mathrm{mg} / \mathrm{kg})$, and $c_{H g, s}$ $(0.004-0.070 \mathrm{mg} / \mathrm{kg})$, as well as the highest levels of $P_{\text {sand }}(32.77-66.02 \%)$; (ii) cluster II, including stations SU03, SG04, SG05, CT04, CT05, MA04, and MA08, distinguished by high values of $h$ (35$67 \mathrm{~m})$ and lowest levels of $c_{A l, s}(19910-35960 \mathrm{mg} / \mathrm{kg})$ and $c_{A s, s}(26.26-58.74 \mathrm{mg} / \mathrm{kg})$; (iii) cluster III, containing stations SU01, SG01, SG03, PO02, PO04, PO05, CT02, CT03, TZ18, MA07, differentiated by the lowest values of $P_{\text {sand }}(0.40-5.82 \%)$ and the highest levels of $c_{A l, s}(53890-64930 \mathrm{mg} / \mathrm{kg})$.

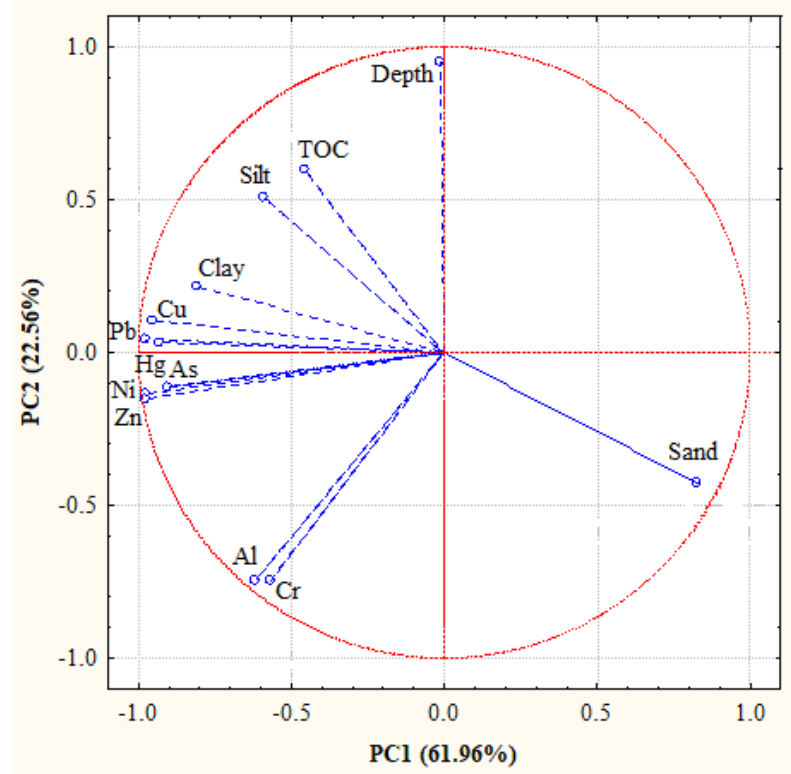

Figure 4. Projections of variables on PC1-PC2 plane

Table 6

Factor coordinates of variables

\begin{tabular}{|c|c|c|c|c|}
\hline \multirow[b]{2}{*}{ No. } & \multicolumn{2}{|c|}{ Variable } & \multirow[b]{2}{*}{ PC1 } & \multirow[b]{2}{*}{$\mathrm{PC} 2$} \\
\hline & Name & $\begin{array}{c}\text { Simbol in } \\
\text { Fig. } 4 \text { and Table } 7\end{array}$ & & \\
\hline 1 & Water depth & Depth & -0.01 & 0.95 \\
\hline 2 & TOC concentration & TOC & -0.45 & 0.59 \\
\hline 3 & Al concentration & $\mathrm{Al}$ & -0.62 & -0.75 \\
\hline 4 & As concentration & As & -0.90 & -0.11 \\
\hline 5 & Cr concentration & $\mathrm{Cr}$ & -0.57 & -0.75 \\
\hline 6 & Ni concentration & $\mathrm{Ni}$ & -0.98 & -0.14 \\
\hline 7 & $\mathrm{Cu}$ concentration & $\mathrm{Cu}$ & -0.96 & 0.10 \\
\hline 8 & Zn concentration & $\mathrm{Zn}$ & -0.98 & -0.15 \\
\hline 9 & $\mathrm{~Pb}$ concentration & $\mathrm{Pb}$ & -0.98 & 0.04 \\
\hline 10 & Hg concentration & $\mathrm{Hg}$ & -0.93 & 0.03 \\
\hline 11 & Sand percentage & Sand & 0.83 & -0.43 \\
\hline 12 & Silt percentage & Silt & -0.59 & 0.51 \\
\hline 13 & Clay percentage & Clay & -0.81 & 0.22 \\
\hline
\end{tabular}


Table 7. Pearson correlation coefficient matrix

\begin{tabular}{|c|c|c|c|c|c|c|c|c|c|c|c|c|c|}
\hline Variable & Depth & $\mathrm{TOC}$ & $\mathrm{Al}$ & $\mathrm{As}$ & $\mathrm{Cr}$ & $\mathrm{Ni}$ & $\mathrm{Cu}$ & $\mathrm{Zn}$ & $\mathrm{Pb}$ & $\mathrm{Hg}$ & Sand & Silt & Clay \\
\hline Depth & 1.00 & 0.56 & -0.67 & -0.10 & -0.70 & -0.10 & 0.12 & -0.13 & 0.07 & 0.05 & -0.38 & 0.43 & 0.21 \\
\hline $\mathrm{TOC}$ & 0.56 & 1.00 & -0.10 & 0.36 & -0.12 & 0.38 & 0.48 & 0.36 & 0.51 & 0.39 & -0.49 & 0.49 & 0.33 \\
\hline $\mathrm{Al}$ & -0.67 & -0.10 & 1.00 & 0.64 & 0.95 & 0.72 & 0.49 & 0.71 & 0.57 & 0.51 & -0.18 & 0.03 & 0.28 \\
\hline $\mathrm{As}$ & -0.10 & 0.36 & 0.64 & 1.00 & 0.56 & 0.90 & 0.86 & 0.91 & 0.86 & 0.77 & -0.67 & 0.51 & 0.63 \\
\hline $\mathrm{Cr}$ & -0.70 & -0.12 & 0.95 & 0.56 & 1.00 & 0.63 & 0.40 & 0.64 & 0.51 & 0.47 & -0.19 & 0.06 & 0.26 \\
\hline $\mathrm{Ni}$ & -0.10 & 0.38 & 0.72 & 0.90 & 0.63 & 1.00 & 0.95 & 0.98 & 0.96 & 0.90 & -0.71 & 0.47 & 0.73 \\
\hline $\mathrm{Cu}$ & 0.12 & 0.48 & 0.49 & 0.86 & 0.40 & 0.95 & 1.00 & 0.94 & 0.97 & 0.90 & -0.78 & 0.54 & 0.78 \\
\hline $\mathrm{Zn}$ & -0.13 & 0.36 & 0.71 & 0.91 & 0.64 & 0.98 & 0.94 & 1.00 & 0.97 & 0.91 & -0.72 & 0.48 & 0.73 \\
\hline $\mathrm{Pb}$ & 0.07 & 0.51 & 0.57 & 0.86 & 0.51 & 0.96 & 0.97 & 0.97 & 1.00 & 0.92 & -0.77 & 0.53 & 0.77 \\
\hline $\mathrm{Hg}$ & 0.05 & 0.39 & 0.51 & 0.77 & 0.47 & 0.90 & 0.90 & 0.91 & 0.92 & 1.00 & -0.76 & 0.44 & 0.86 \\
\hline $\mathrm{Sand}$ & -0.38 & -0.49 & -0.18 & -0.67 & -0.19 & -0.71 & -0.78 & -0.72 & -0.77 & -0.76 & 1.00 & -0.85 & -0.84 \\
\hline $\mathrm{Silt}$ & 0.43 & 0.49 & 0.03 & 0.51 & 0.06 & 0.47 & 0.54 & 0.48 & 0.53 & 0.44 & -0.85 & 1.00 & 0.43 \\
\hline $\mathrm{Clay}$ & 0.21 & 0.33 & 0.28 & 0.63 & 0.26 & 0.73 & 0.78 & 0.73 & 0.77 & 0.86 & -0.84 & 0.43 & 1.00 \\
\hline
\end{tabular}

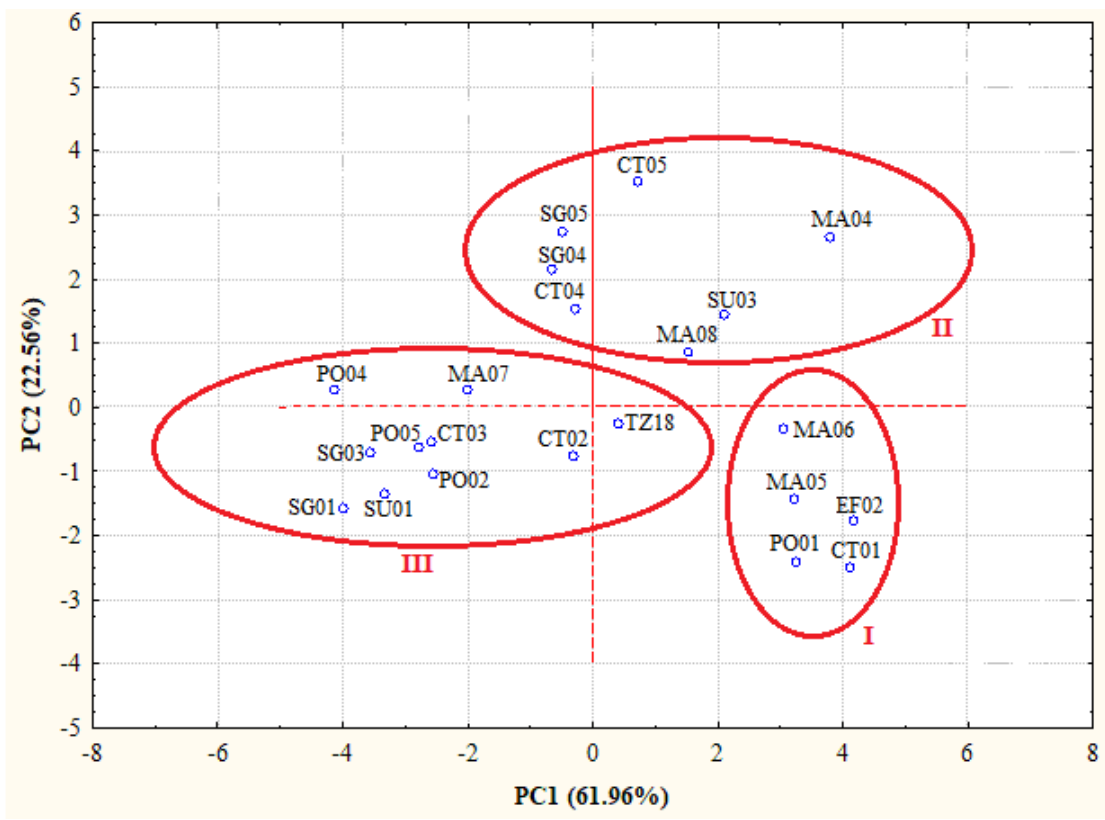

Figure 5. Projections of cases (stations) on PC1-PC2 plane

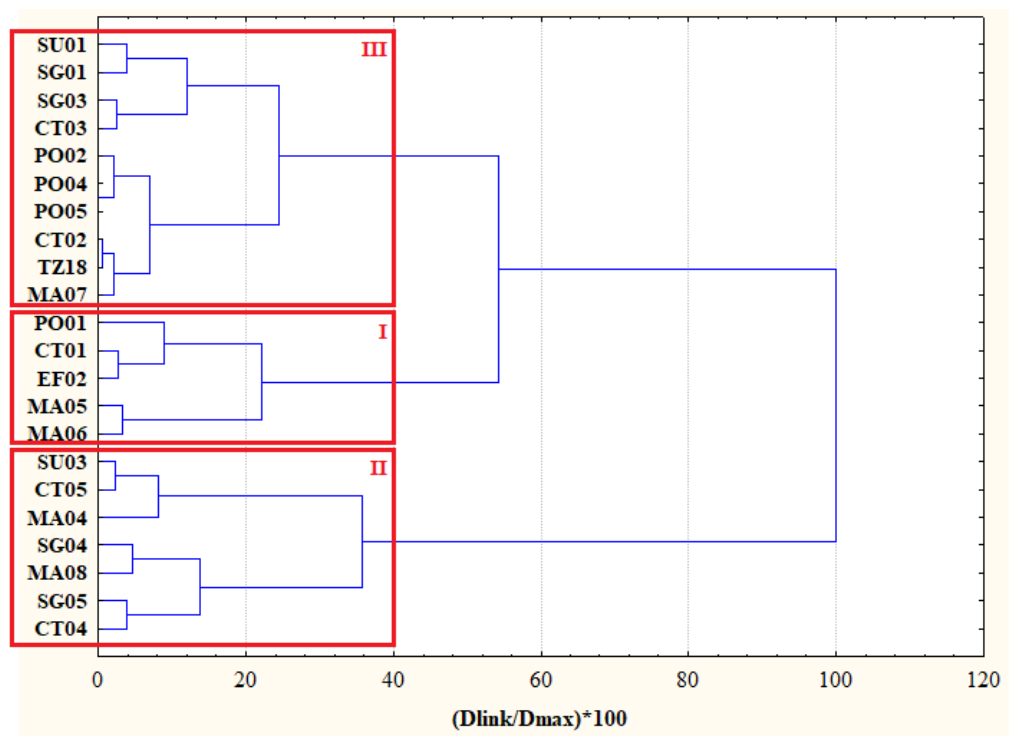

Figure 6. Tree diagram for 22 cases (complete linkage and Euclidean distances) 
Data shown in Figure 5 indicate good discriminations between clusters I and III on the PC1 direction and between clusters I and II on the PC2 direction.

PC1 coordinates of stations belonging to clusters I (3.05-4.19) and III (-4.13-0.42) highlight a discrimination between stations in cluster III, characterized by lowest percentages of sand $(0.40$ $5.82 \%)$ and higher levels of clay (27.68-48.50\%) and heavy metals, i.e., As (6.46-17.16 mg/kg), Ni (36.39-59.30 mg/kg), Cu (19.03-52.47 mg/kg), Zn (72.20-118.5 mg/kg), Pb (22.69-42.07 mg/kg), and $\mathrm{Hg}(0.085-0.230 \mathrm{mg} / \mathrm{kg})$, and those in cluster I with highest percentages of sand $(32.77-66.02 \%)$ and lower levels of clay $(4.50-12.75 \%)$, As $(3.79-4.97 \mathrm{mg} / \mathrm{kg}), \mathrm{Ni}(22.65-31.87 \mathrm{mg} / \mathrm{kg}), \mathrm{Cu}(6.87-$ $13.72 \mathrm{mg} / \mathrm{kg}), \mathrm{Zn}(36.84-51.55 \mathrm{mg} / \mathrm{kg}), \mathrm{Pb}(12.71-14.46 \mathrm{mg} / \mathrm{kg})$, and $\mathrm{Hg}(0.004-0.070 \mathrm{mg} / \mathrm{kg})$.

PC2 coordinates of stations in clusters I (from -2.51 to -0.34) and II (0.85-3.52) show a distinction between stations in cluster I, differentiated by the lowest values of water depth (13.5-27 m) and higher levels of $\mathrm{Al}(40540-50550 \mathrm{mg} / \mathrm{kg})$ and $\mathrm{Cr}(66.15-84.95 \mathrm{mg} / \mathrm{kg})$, and those in cluster II with higher values of water depth $(35-67 \mathrm{~m})$ and lower levels of Al $(19910-35960 \mathrm{mg} / \mathrm{kg})$ and $\mathrm{Cr}(26.26-58.74$ $\mathrm{mg} / \mathrm{kg})$.

\section{Pollution indices}

Descriptive statistics (minimum, maximum, mean, median, standard deviation, and coefficient of variation) related to pollution indices corresponding to each metal, i.e., $E F, C F$, and $I_{g e o}$, which were estimated using Eqs. (1)-(3), are summarized in Table 8.

Table 8. Descriptive statistics for pollution indices

\begin{tabular}{|c|c|c|c|c|c|c|c|c|}
\hline Pollution index & Descriptives & As & $\mathrm{Cr}$ & $\mathrm{Ni}$ & $\mathrm{Cu}$ & $\mathrm{Zn}$ & $\mathrm{Pb}$ & $\mathrm{Hg}$ \\
\hline \multirow{6}{*}{$\begin{array}{l}\text { Enrichment } \\
\text { factor }(E F)\end{array}$} & Min & 0.56 & 1.10 & 0.61 & 0.27 & 0.73 & 1.13 & 0.43 \\
\hline & Max & 2.20 & 1.86 & 1.92 & 2.64 & 2.09 & 4.36 & 4.39 \\
\hline & Mean & 1.21 & 1.43 & 1.06 & 1.15 & 1.40 & 2.24 & 2.52 \\
\hline & Median & 1.22 & 1.41 & 1.07 & 1.21 & 1.49 & 2.25 & 2.58 \\
\hline & SD & 0.45 & 0.18 & 0.31 & 0.60 & 0.43 & 0.85 & 1.24 \\
\hline & $\mathrm{CV}$ & 0.37 & 0.13 & 0.30 & 0.52 & 0.31 & 0.38 & 0.49 \\
\hline \multirow{6}{*}{$\begin{array}{l}\text { Contamination } \\
\text { factor }(C F)\end{array}$} & Min & 0.26 & 0.29 & 0.28 & 0.15 & 0.29 & 0.58 & 0.25 \\
\hline & $\operatorname{Max}$ & 1.32 & 1.12 & 0.87 & 1.17 & 1.25 & 2.10 & 2.88 \\
\hline & Mean & 0.68 & 0.81 & 0.58 & 0.63 & 0.78 & 1.22 & 1.41 \\
\hline & Median & 0.65 & 0.86 & 0.55 & 0.68 & 0.76 & 1.26 & 1.47 \\
\hline & SD & 0.33 & 0.25 & 0.20 & 0.34 & 0.31 & 0.46 & 0.80 \\
\hline & $\mathrm{CV}$ & 0.48 & 0.30 & 0.34 & 0.54 & 0.40 & 0.38 & 0.57 \\
\hline \multirow{6}{*}{$\begin{array}{l}\text { Geo- } \\
\text { accumulation } \\
\text { index }\left(I_{g e o}\right)\end{array}$} & Min & -2.51 & -2.36 & -2.40 & -3.30 & -2.35 & -1.37 & -2.58 \\
\hline & Max & -0.18 & -0.43 & -0.78 & -0.36 & -0.27 & 0.49 & 0.94 \\
\hline & Mean & -1.31 & -0.97 & -1.45 & -1.52 & -1.06 & -0.41 & -0.38 \\
\hline & Median & -1.22 & -0.80 & -1.44 & -1.15 & -0.99 & -0.25 & -0.03 \\
\hline & SD & 0.73 & 0.55 & 0.51 & 0.98 & 0.62 & 0.59 & 1.03 \\
\hline & $\mathrm{CV}$ & 0.56 & 0.57 & 0.36 & 0.64 & 0.59 & 1.44 & 2.68 \\
\hline
\end{tabular}

Spatial distributions of $E F_{i}$ (Figure 7) show values between 0.27 and 4.39 (no, minor, and moderate pollution), with a minimum for $\mathrm{Cu}$ at the station $\mathrm{EF02}$ and a maximum for $\mathrm{Hg}$ at the station SG05. ANOVA one way test followed by Tuckey (HSD) multiple comparison test revealed significant higher values only for $\mathrm{Pb}$ and $\mathrm{Hg}$.

Values of $E F_{i}$ greater than 3, suggesting moderate enrichment, were found only for $\mathrm{Pb}$ (maximum of 4.36) and $\mathrm{Hg}$ (maximum of 4.39). Higher values of $E F_{P b}$ and $E F_{H g}$ found at stations SG04 (3.66 and 3.61), SG05 (3.03 and 4.39), CT04 (2.97 and 3.34), and CT05 (4.36 and 4.00), which are situated on the Danube's plume direction, can be related to the riverine discharges. Moreover, higher levels of $E F_{H g}(3.42-4.03)$ were detected at stations located in the Portita Bay (except PO01), most probable linked to the oil and gas extraction activities in this area, at station SG01 (3.31), due to the direct 
influence of the Sf. Gheorghe branch, and also at station MA08 (4.03), possibly related to the local regime of currents carrying on the wastewater and industrial discharges.

Lower levels of $E F_{P b}(1.13-1.30)$ and $E F_{H g}(0.43-0.79)$ were observed at shallow stations PO01, CT01, EF02, and MA06, characterized by lower clay contents (4.50-11.43\%) and higher sand percentages (36.75-66.02\%). Moreover, the lowest values of $E F_{i}$ for $\mathrm{Pb}(1.13)$ and $\mathrm{Hg}(0.43)$ were found at the station EF02, from which sediments with the lowest clay content $(4.50 \%)$ and the highest sand content $(66.02 \%)$ were collected. These findings suggest the influence of the sediment type on the pollution level.

All values of $E F_{C r}(1.10-1.86)$ were in the range of 1-3 (minor enrichment), with higher ones in the shallower waters in front of Mangalia, i.e., stations MA05 (1.61), MA06 (1.86), and MA08 (1.72), and on the Danube's plume direction, including stations SU03 (1.63) and SG04 (1.64).

$68 \%$ of values of $E F_{N i}(0.61-1.92)$ and $E F_{C u}(0.27-2.64)$ are between 1 and 3, higher ones being on the Danube's plume direction, at stations SG04 (1.41 and 1.79), SG05 (1.46 and 1.83), and CT05 (1.92 and 2.64). 73\% of values of $E F_{A s}(0.56-2.20)$ and $E F_{Z n}(0.73-2.09)$ are in the range of 1-3, maximum levels being determined on the Danube's plume direction, at stations CT05 for Zn and SG04 for As, respectively.

Similar to $\mathrm{Pb}$ and $\mathrm{Hg}$, the lowest values of $E F_{i}$ for $\mathrm{Ni}(0.62), \mathrm{Cu}(0.27), \mathrm{Zn}(0.73)$, and $\mathrm{As}(0.56)$ were found at the station EF02, where the sediments had the lowest clay content and the highest sand content. Morever, lower levels of $E F_{i}$, i.e., 0.56-0.64 for As, 0.61-0.74 for Ni, 0.27-0.48 for $\mathrm{Cu}, 0.73-$ 0.86 for Zn, were also found at the stations PO01, CT01, EF02, MA05, and MA06, characterized by lower clay contents and higher sand percentages.
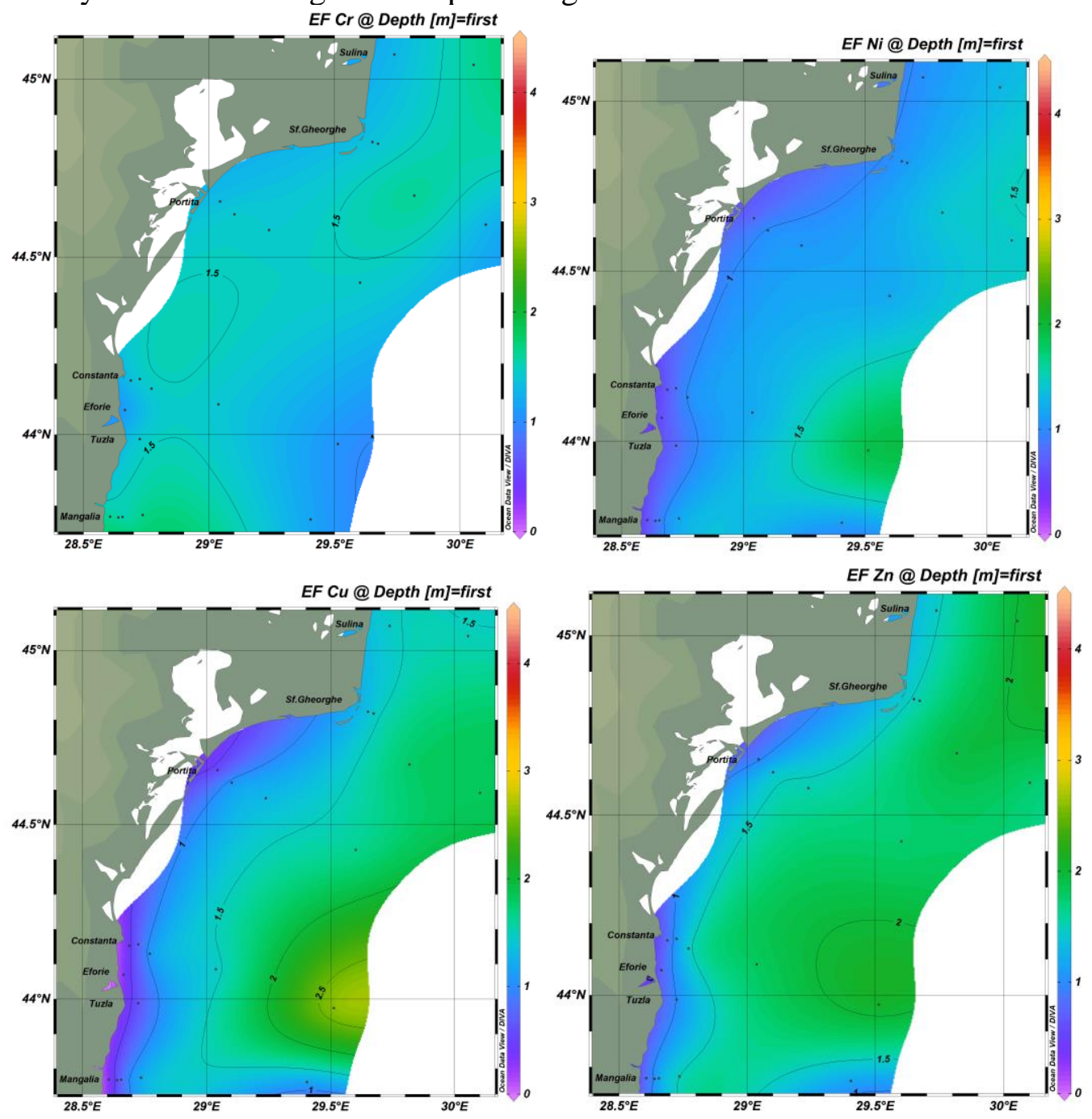

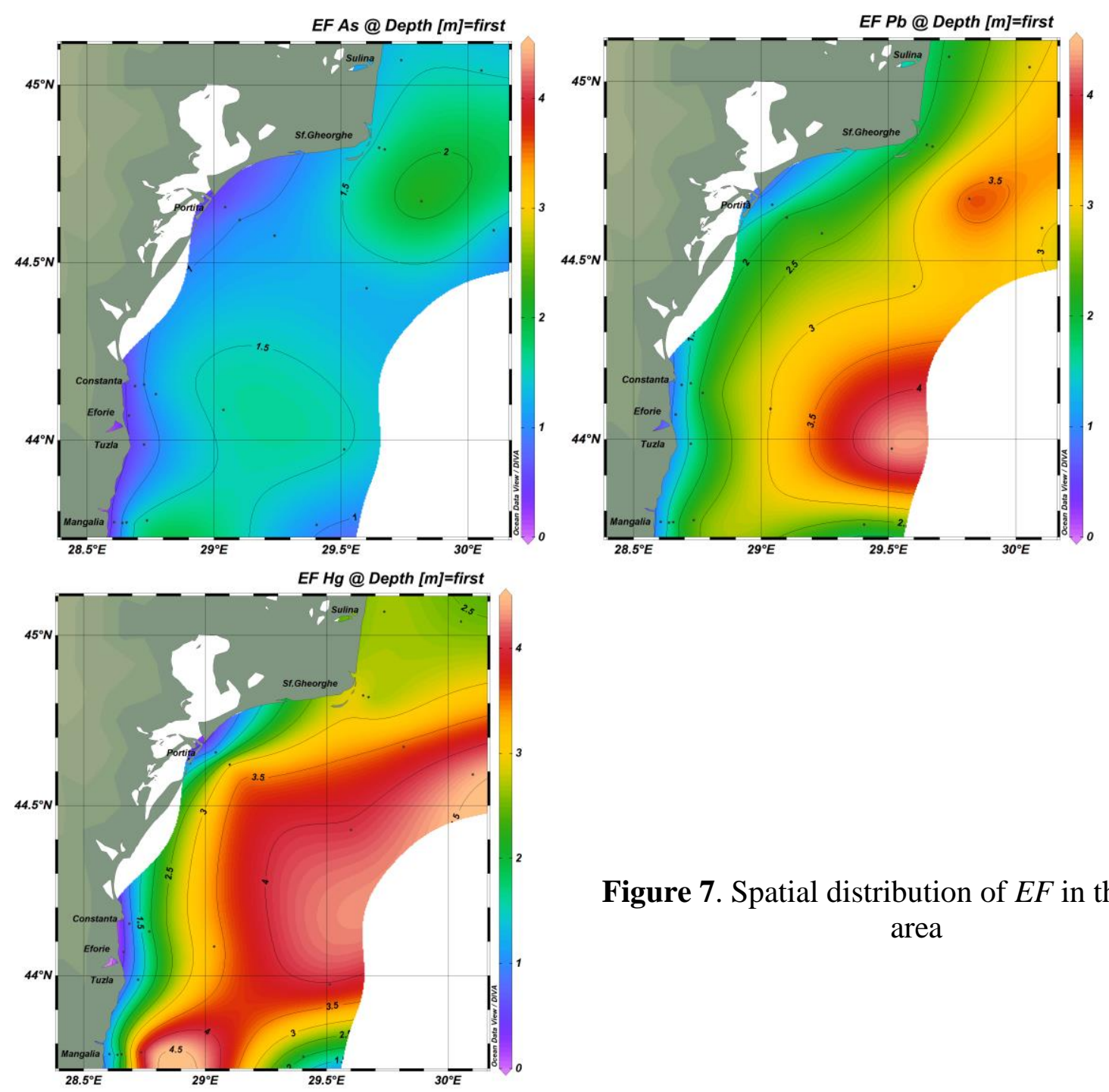

Figure 7. Spatial distribution of $E F$ in the studied area

Spatial distributions of $C F_{i}(0.15-2.88)$, which are shown in Figure 8, emphasize low $\left(C F_{i}<1\right)$ and moderate $\left(1<C F_{i}<3\right)$ metal contamination for all 22 stations. Similar to $E F_{i}$, ANOVA one way test followed by Tuckey (HSD) multiple comparison test revealed significant higher values of $C F_{i}$ only for $\mathrm{Hg}$ and $\mathrm{Pb}$ as compared to the rest of analyzed elements. Referring to the values of $C F_{P b}(0.58-2.10)$ and $C F_{H g}(0.25-2.88)$, there is a moderate contamination at 13 stations (SU01, SG01, SG03-05, PO02, PO04, PO05, CT02-05, and MA07) for both metals as well as at stations TZ18 for Pb and MA08 for $\mathrm{Hg}$. Relatively higher values of $C F_{P b}$ and $C F_{H g}$ detected at stations CT02, CT03, TZ18, MA07, and MA08 are most probable linked to the coastal anthropogenic pressures resulting from the port activities, tourism, and urban wastewater discharges.

Values of $C F_{N i}(0.28-0.87)$ indicate only low contamination. Values of $C F_{C r}(0.29-1.12)$ and $C F_{Z n}$ (0.29-1.25) are more than 1 in the Danube's mouth area (SU01, SG01, and SG03), in the Portita Bay (PO2, PO4, and PO5), and in the Constanta area (CT03). Values of $C F_{C u}(0.15-1.17)$ and $C F_{A s}(0.26-$ 1.32) are higher than 1 in front of the Danube's mouths (SU01, SG01, and SG03) as well as at the eastern limit of the Portita Bay (PO04) for $\mathrm{Cu}$ and at station MA07 for As.

The lowest values of $C F_{i}$ were found generally at the easternmost station from the Mangalia area, MA04 $\left(C F_{C r}=0.29, C F_{N i}=0.28, C F_{Z n}=0.29, C F_{A s}=0.26\right.$, and $\left.C F_{P b}=0.58\right)$, where the Danube's influence is significantly weaker. The values of $C F_{i}$ for $\mathrm{Cu}$ and $\mathrm{Hg}$ were minimum at stations characterized by higher levels of $P_{\text {sand }}\left(C F_{C u}=0.15\right.$ at stations EF02 and MA06 and $C F_{H g}=0.25$ at station EF02). 


\section{Revista de Chimie}
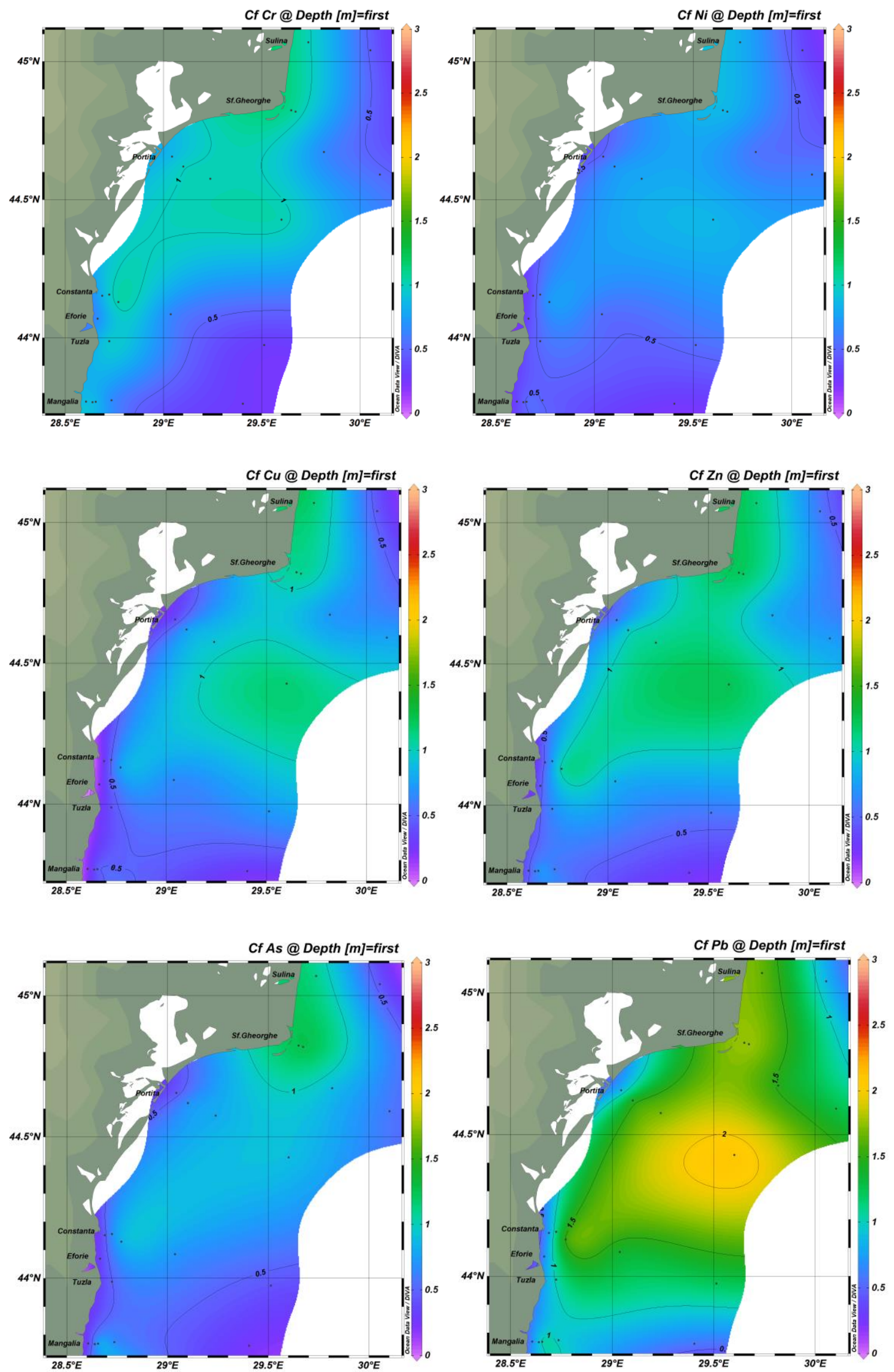


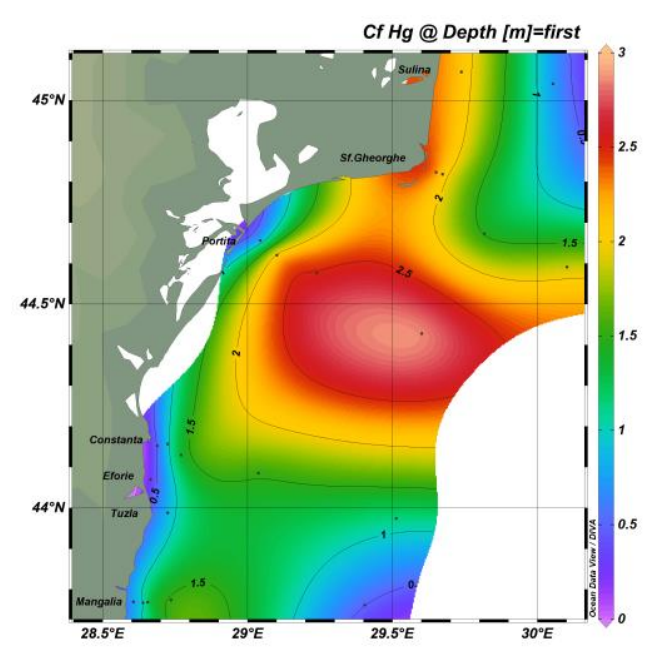

Figure 8. Spatial distribution of $C F$ in the studied area

Characteristic values of $I_{g e o, i}$ for $i=\mathrm{As}, \mathrm{Cr}, \mathrm{Ni}, \mathrm{Cu}, \mathrm{Zn}$ are below 0 , indicating unpolluted sediments with respect to these elements. Levels of both $I_{g e o, P b}(-1.37-0.49)$ and $I_{g e o, H g}(-2.58-0.94)$ are in the range of $0-1$ at 3 stations in the Danube's mouth area (SU01, SG01, and SG03), 3 stations in the Portita Bay (PO2, PO4, and PO5), and 1 station in the Constanta area (CT03), whereas values of $I_{g e o, H g}$ are higher than 0 at the stations SG05 (0.3) and MA07 (0.2), indicating uncontaminated to moderately contaminated sediments. Spatial distributions of $I_{g e o, P b}$ and $I_{g e o, H g}$ in the studied area are shown in Figure 9.
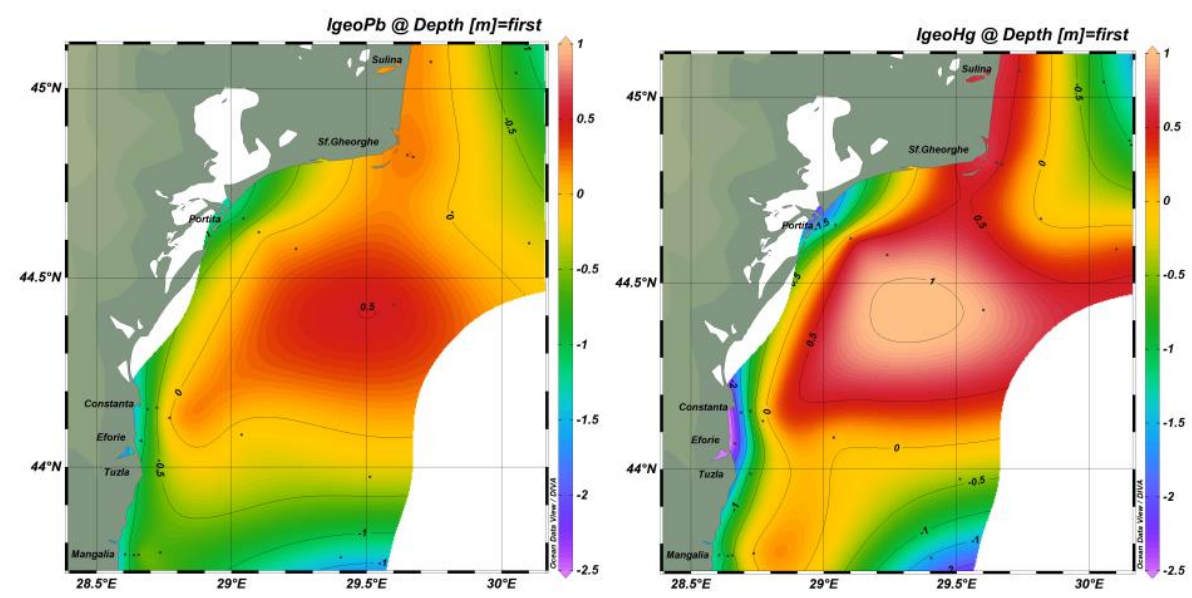

Figure 9. Spatial distribution of $I_{g e o}$ for $\mathrm{Pb}$ and $\mathrm{Hg}$ in the studied area

\section{Conclusions}

Spatial distributions of some trace elements (As, $\mathrm{Cr}, \mathrm{Ni}, \mathrm{Cu}, \mathrm{Zn}, \mathrm{Pb}$, and $\mathrm{Hg}$ ) and $\mathrm{Al}$ in the surface sediments collected from NW Black Sea were determined. Mean values of heavy metal concentrations $(0.11-74.11 \mathrm{mg} / \mathrm{kg})$ decreased in the order: $\mathrm{Zn}>\mathrm{Cr}>\mathrm{Ni}>\mathrm{Cu}>\mathrm{Pb}>\mathrm{As}>\mathrm{Hg}$. The elements considered in this study showed relatively large spatial variability with higher concentrations in front of the Danube's mouths and at eastern edge of the Portita Bay.

Multivariate analysis revealed that $\mathrm{As}, \mathrm{Ni}, \mathrm{Cu}, \mathrm{Zn}, \mathrm{Pb}$, and $\mathrm{Hg}$ concentrations had similar behavior and they were positively correlated with the clay content, whereas $\mathrm{Al}$ and $\mathrm{Cr}$ contents presented close patterns and they were negatively correlated with the water depth. Three clusters of stations having dissimilar metal accumulation in the surface sediments were obtained.

Different indices used to evaluate the degree of pollution of the Romanian inner shelf sediments suggest that most metal concentrations in the sediments were, generally, at natural levels. Dominant heavy metal pollution in the Romanian inner shelf sediments came from $\mathrm{Pb}$ and $\mathrm{Hg}$. The values of $E F$, $C F$, and $I_{g e o}$ indices suggest a higher sediment pollution with $\mathrm{Pb}$ and $\mathrm{Hg}$ along the Danube's plume 
direction, the oil platform area (eastern edge of the Portita Bay), and partially in the Constanta and Mangalia areas, indicating the influence of oil and gas extraction, port activities (ships berthing, shipyards, handling activities of bulky goods and sewage outfall), tourism, and urban wastewater discharges.

Acknowledgments. The present study has been supported by the Ministry of Research and Innovation (Romania) within the framework of the Nucleus Program, the project PN18 160203 - Geo-ecological monitoring of the Romanian Black Sea shelf, as well as the Project Research of Excellence FLUVIMAR no. 8PFE/16.10.2018.

\section{References}

1.SECRIERU, D., SECRIERU, A., Estuar. Coast. Shelf Sci., 54, 2002, p. 513.

2.MEE, L.D., TOPPING, G., Black Sea pollution assessment, Black Sea Environmental Series, 10, UN Publications, New York, 1998.

3.BUCCOLIERI, A., BUCCOLIERI, G., CARDELliCCHIO, N., DELL'ATTI, A., DI LEO, A., MACI, A., Mar. Chem., 99, nos. 1-4, 2006, p. 227.

4.DOU, Y., LI, J., ZHAO, J., HU, B., YANG, S., Mar. Pollut. Bull., 67, 2013, p. 137.

5.FERNANDES, L., NAYAK, G.N., ILANGOVAN, D., BOROLE, D.V., Estuar. Coast. Shelf Sci., 91, 2011, p. 388.

6.HU, B., CUI, R., LI, J., WEI, H., ZHAO, J., BAI, F., SONG, W., DING, X., Mar. Pollut. Bull., 76, 2013, p. 400.

7.REMEIKAITÉ-NIKIENE， N., GARNAGA-BUDRĖ， G.， LUJANIENĖ， G.， JOKŠAS， K., STANKEVIČIUS, A., MALEJEVAS, V., BARISEVIČIŪTĖ, R., Oceanologia, 60, no. 2, 2018, p. 193.

8.ABOD, B.M., AL-ALAWY, R.M.J., KAMAR, F.H., NECHIFOR, G., Rev. Chim.,70, (5), 2019, 1507.

9.ALDA, S., NITA, S., NITA, L.D., RADA, M., BORDEAN, D.M., ALDA, L.M., Rev. Chim. 69, (5), 2018, p. 1145.

10.SEDRATI, A., HOUHA, B., ROMANESCU, G., SANDU, I.G., DIACONU, D.C., SANDU, I., Rev. Chim., 68, (2), 2017, 420.

11.SIMONESCU, C.M., TANASE, I.R., PURCARU, I.N., TARDEI, MARINESCU, V., Rev. Chim., 70, (5), 2019, p. 1758.

12.STEFAN, D.S., NEACSU, N., PASCU, L.F., SERBANESCU, C., STEFAN, M., Rev. Chim., 68, (2), 2017, 215.

13.VASILE, G.G., GHEORGHE, S., ENE, C., SERBAN, E.A., STOICA, C., Rev. Chim., 70, (1), 2019, 263.

14.GARGOURI, D., AZRI, C., SERBAJI, M.M., JEDOUI, Y., MONTACER, M., Environ. Monit. Assess., 175, 2011, p. 519.

15.HÅKANSON, L., Water Res., 14, 1980, p. 975.

16.MÜLLER, G., Umschau, 79, 1979, p.778.

17.MÜLLER, G., Chem. Zeit., 105, 1981, p. 157.

18.WANG, Y., YANG, L., KONG, L., LIU, E., WANG, L., ZHU, J., Catena, 125, 2015, p. 200.

19.ZALEWSKA, T., WORON, J., DANOWSKA, B., SUPLINSKA, M., Oceanologia, 57, 2015, p.32.

20.MORILLO, J., USERO, J., GRACIA, I., Chemosphere, 55, 2004, p. 431.

21.SHEPARD, F.P., Journal of Sedimentary Research, 24, no. 3, 1954, p. 151.

22.GAUDETTE, H.E., FLIGHT, W.R., TONER, L., FOLGER, D.W., Journal of Sedimentary Petrology, 44, 1974, p. 249.

23.TUREKIAN, K.K., WEDEPOHL, K.H., 1961, Geol. Soc. Am. Bull., 72, p. 175.

24.SCHLITZER, R., Comput. Geosci.-UK, 28, 2002, p. 1211.

25.OROS, A., PhD Thesis, Constanta, 2009.

$\overline{\text { Manuscript received: } 6.07 .2019}$ 
